\title{
Smallholder Households' Willingness to Pay for Conservation of Ecosystem Services of Alitash National Park, Ethiopia
}

Agerie Nega Wassihun ( $\nabla$ agerie.nega@yahoo.com )

University of Gondar Faculty of Agriculture

Fikeremaryam Birara Feleke

University of Gondar Faculty of Agriculture

Gebrehiwot Abebe Bayeh

University of Gondar Faculty of Agriculture

Yitayew Malede Nega

University of Gondar Faculty of Agriculture

\section{Research}

Keywords: Alitash National Park, Contingent valuation method, Economic valuation, Ecosystem services, Seemingly unrelated bivariate probit, Willingness to pay

Posted Date: August 10th, 2021

DOI: https://doi.org/10.21203/rs.3.rs-744902/v1

License: (c) (i) This work is licensed under a Creative Commons Attribution 4.0 International License. Read Full License

Version of Record: A version of this preprint was published at International Journal of Geoheritage and Parks on November 1st, 2021. See the published version at https://doi.org/10.1016/j.ijgeop.2021.11.002. 
1 SMALLHOLDER HOUSEHOLDS' WILLINGNESS TO PAY FOR

2 CONSERVATION OF ECOSYSTEM SERVICES OF ALITASH NATIONAL

3 PARK, ETHIOPIA

4

5 Agerie Nega Wassihun*, Fikeremaryam Birara Feleke, Gebrehiwot Abebe Bayeh,

$6 \quad$ Yitayew Malede Nega

7

8 Current institutional address of all Authors:

9 Department of Agricultural Economics, College of Agriculture and Environmental 10 Sciences, University of Gondar, P.O.Box 196 Gondar, Ethiopia (E-mail:

11 agerie.nega@yahoo.com (*Corresponding author) fbirara291@gmail.com;

12 ghiwot21@gmail.com; yitayewmaledeyitayew@gmail.com, respectively)

13

14 Corresponding Author Orcid: https://orcid.org/0000-0002-7531-5424

15

16

17

18

19

20

21

22

23

24

25 
Abstract

28 Background: Despite exceptional ecosystem services are provided by Altash National Park, anthropogenic activities exert immense pressures on the parks' natural resources from the surrounding community which is eventually degrading the productivity of ecosystem services.

31 Therefore, the aim of this study was economic valuation of ecosystem services of Altash National

32 Park of Ethiopia. Using systematic random sampling 196 sample respondents were selected. Double bounded dichotomous choice followed by open ended format of contingent valuation method was used to state households' willingness to pay (WTP) and their maximum WTP for conservation of ecosystem services of the park. Seemingly unrelated bivariate probit model was employed to analyse the data.

37 Results: First and second offered bid values, Sex of respondent, Years of living in Kebele, Education status, Distance from home to park, Benefit of preservation, Distance from farm to park, Training on park conservation were found to have statistically significant influence on households' WTP for improving conservation of ecosystem services of the park. The expected aggregate WTP from double bounded dichotomous choice and open ended format was estimated 1,511,172.96 and $42 \quad 1,526,194.56$ birr, respectively.

43 Conclusions: Based on the findings, since all respondents were willing to pay for the conservation 44 of ecosystem services of the park, for every decision and formulation of policies and strategies, 45 participation of local communities should be considered. Finally, regular training and workshop 46 should be delivered for local communities to enhance awareness about the environmental and 47 economic values of the park and to develop sense of ownership.

48 Key Words: Alitash National Park; Contingent valuation method; Economic valuation;

49 Ecosystem services; Seemingly unrelated bivariate probit; Willingness to pay 


\section{INTRODUCTION}

\subsection{Background of the Study}

In all parts of Africa and globe, national parks are the most extensive form of protected areas which comprise approximately $23 \%$ of the global protected areas. According to Assefa et al., (2017) more than 1,812 national parks were built before 2013 in Africa. National parks are crucial for conservation and preservation of biodiversity and provision of other benefits associated with the maintenance of ecological integrity (Bhat, 2016; Bhat \& Sinha, 2016). Environmental resources provide significant contribution for human beings, plants and animals day to day activities (Endalew et al., 2018). Most of the ecosystem service values of national park are non -market values. As a result, there is no market clearing prices for goods and services derived from the natural ecosystem, due to this, it is impossible to estimate the full value of protecting vibrant ecosystem services (Haefele \& Loomis, 2016).

Ecosystem services are the benefits that people and societies derive from the natural processes that sustain ecosystems (Daily, 1997 cited in Zhu et al., 2010 and Millennium Ecosystem Assessment, 2005); and they can be generally cataloged into four broad areas as summarized by (Millennium Ecosystem Assessment, 2005; Zhu et al 2010; Gebre et al., 2016; PAN UK, 2017 and Sahle Tesfaye, 2019), the ecosystem provides us different services: - provisioning services (like fiber, food supply, fresh water supply, biomass fuel, genetic resources, natural medicines, etc.), regulating services (like, air quality, climate change stabilization by carbon sequestration, water erosion, water purification and waste treatment; pest and regulation services, etc.), and supportive services (like, soil formation, pollination, nutrient cycling, primary production, water cycling, habitat etc.) are provided to the dwellers of the ecosystem. Furthermore, the cultural services are education, recreation/aesthetic, eco-tourism, spiritual, etc. The decision associated with this ecosystem services are expansion of social and physical infrastructures which negatively harm the ecosystem practices of services and reforestation and afforestation practices of the decision enhances the ecosystem service.

Ethiopia as a country is gifted with several cultural and natural fascinations from the tops of the rugged Simien Mountains to the depths of the Danakil Depression, at 120 meters below sea level with high appealing value. 
Protected areas for wildlife and forest conservation covers about $14 \%$ of the total land area of the country. However, the country is one of the least beneficiaries of the growing tourism industry in Africa. The summation of use value and non-use value that people attach to environmental goods and services is the total economic value (TEV). The benefit that human beings get by making actual use of the good currently or in the future refers to use value while the non-instrumental values which are in the real nature of the resource but unassociated with either actual use, or the option to use in the future is referred to as non-use value (Mossie et al., 2019; Shamsudin, et al., 2009).

Ethiopia established different National Parks and protected areas at different level which play crucial role for biodiversity conservation and ecotourism expansion which can have significant economic impact specifically for the society living in the vicinity of the park and the national income in general (Sherif, 2019; Walle, 2015). Altash National park is a newly established National Park of the country and it is the home of endemic bird and animal species, and wood lands. Despite exceptional ecosystem services provided by the park, anthropogenic activities exert immense pressures on the parks' natural resources from the surrounding community which is eventually degrading the productivity of ecosystem services. Currently the park faced several problems like, extensive overgrazing, increasing demand for fuel wood and charcoal as a source of income, farm land expansion, uncontrolled fire and hunting, cutting of tree for house construction and fence. Therefore, protecting and conserving the park is essential mainly for three purposes: First, since the park is an ideal for recreational site, it increases revenue for the community and the government. Second, it maintains the ecological balance of the area since the park is covered by dense forest. Lastly, the endemic animal and bird species will be protected. According to the literature review, so far there is no study conducted on economic valuation of ecosystem services of Altash National Park. Therefore, the aim of this study was: (1) To elicit households' willingness to pay for conservation of ecosystem services of Altash National Park; (2) To examine determinant factors that influence variation in households' WTP for conservation of ecosystem services of the park; (3) To estimate households' mean and aggregate WTP for conservation of ecosystem services of Altash National Park of Ethiopia. 


\subsection{Description of Study Area}

114 This study was conducted in QuaraWoreda, West Gondar Zone of Amhara National Regional State 115 of Ethiopia. Particularly the study focused on Alitash National Park which is located in the South

116 Western part of Quara Woreda, West Gondar Zone (Figure 1). Alitash National Park is a newly 117 established national park. It is established on $20^{\text {th }}$ February 2006. It has an area of 2,665.7 $\mathrm{km}^{2}$ 118 lying between $11^{\circ} 47^{\prime} 5.4^{\prime \prime}$ to $12^{\circ} 31^{\prime} 3.6^{\prime \prime} \mathrm{N}$ latitude and $35^{\circ} 15^{\prime} 48^{\prime \prime}$ to $35^{\circ} 48^{\prime} 51^{\prime \prime}$ E longitude in 119 north western flat plain part of Ethiopia. Alitash National Park is bordered with Sudan (Dinder 120 National Park) in the West, in the South Benshangul Gumuz National Regional State with Ayma 121 river, Bambaho and Gelgu in the East and in the North direction it is bordered by Mehadid, 122 Brermel, Gumz Wuha and Mosabadema peasant association of Quara District (Bekele, A \& 123 Mengesha,G 2008).

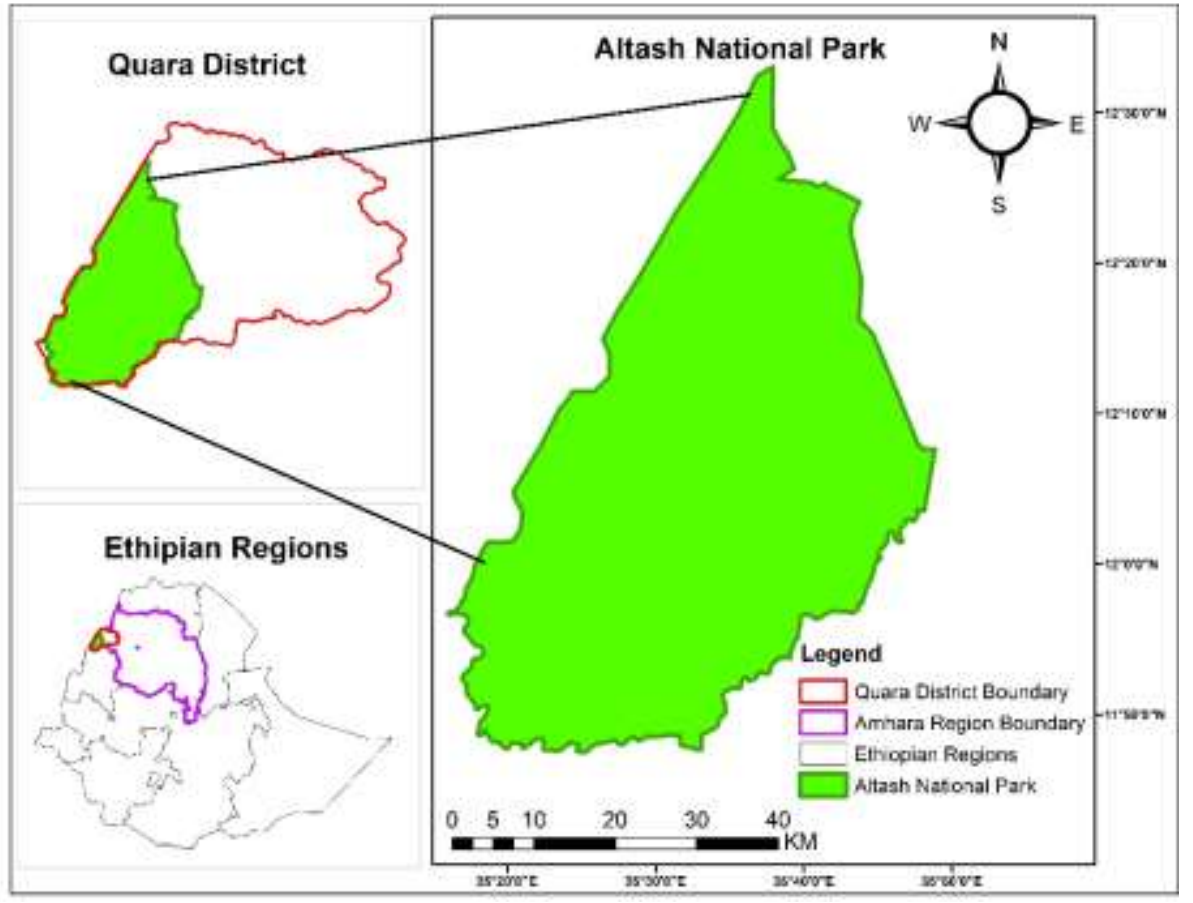

Figure 1: Map of study area.

\subsection{Sample Size and Sampling Method}

127 To select sample respondents multi-stage sampling technique were used. In the first stage, Quara 128 District was selected purposively because Altash National Park is found within this district. In the second stage six kebelles were being randomly selected. 
In the third stage a total of 196 sample respondents were being selected by using systematic random sampling method taking in to account the proportion of households in each kebelle. To obtain a representative sample size, for cross-sectional household survey the study was employ the sample size determination formula developed by Kothari (2004) as follows:

$$
n=\frac{Z^{2} p q}{e^{2}} \quad=\frac{1.96^{2} \times 0.5 \times 0.5}{0.07^{2}}=196
$$

Where; $\mathrm{n}=$ Sample size; $\mathrm{Z}=$ confidence level $(\alpha=0.05$, hence, $Z=1.96) ; \mathrm{p}=$ proportion of the population containing the major interest, $\mathrm{q}=1-\mathrm{p}$ and $\mathrm{e}=$ allowable error.

\subsection{Methods of Data Collection}

The socio-economic primary data was collected through personal and face-to-face interview using semi-structured and pre-tested interview schedule that was filled up by recruited and trained enumerators under the close supervision of the researchers. Moreover, focus group discussion and key informant interview and also direct personal observation was carried out to triangulate the data obtained from survey. To address economic valuation of the park, a stated preference approach of which contingent valuation method was employed to elicit households' WTP for conservation of the park. There are different elicitation methods used to estimate willingness to pay from a sample of households in contingent valuation surveys. The most commonly and widely used elicitation formats are open ended, bidding game, payment card, single bounded dichotomous choice, and double bounded dichotomous choice formats. Among them especially dichotomous choice (DC) format is the most widely used (Ahmed and Gotoh, 2006). The other three methods have been shown to suffer from incentive compatibility problems in which survey respondents can influence potential outcomes by revealing values other than their true willingness to pay. Therefore, in this study double bounded dichotomous choice format was carried out. Moreover, to increase the precision of the estimate with dichotomous choice question, open ended follow up questions were also used. Secondary data were being obtained from various sources such as reports of bureau of Tourism and Agriculture at different levels, NGOs, district administrative office, relevant previous published and unpublished research findings. 


\subsection{Methods of Data Analysis}

157 To analyse the two binary response variables which vary jointly in double bounded dichotomous choice format of contingent valuation method, seemingly unrelated bivariate probit model was used. In double bounded dichotomous choice format, respondents were asked whether they would to pay for conservation of the park using two follow-up bid value questions in which the second question is based on respondents' response on the first question. Sets of bid values are determined in double bounded dichotomous choice format by making twice the first bid value if the respondent response is "yes" for the first offered bid value and if the respondent protest against the first offered bid value, half of the first bid value was proposed (Cameron and Quiggin 1994). In this study, for the corresponding scenario valuation question four starting bid values were used. Pilot survey was undertaken on 25 randomly selected households through open ended format to set these starting bid values. In order to avoid bias, responses of these households were not included in the final analysis. Consequently, the most frequently stated bid values in the pilot survey was taken as initial bids for the double bounded dichotomous choice format. Therefore, 60, 70, 80, and 90 birr were taken for the initial bid values. These initial bid values were randomly and evenly distributed to 196 sample household questionnaire and respondents were asked questions about their willingness to pay for conservation of the park with any one of the four pre-determined first bid value and the corresponding second bid determined based on respondents response on the first question. Therefore, the sets of bid values in this study were $(60,30,120),(70,35,140),(80,40,160),(90,45,180)$.

The significance level of rho $(\rho)$, which shows the value of the correlation coefficient between random errors of the two equations was checked to select whether univariate or bivariate probit model is fitted for analysis. Accordingly, in the estimates of seemingly unrelated bivariate probit model (Table 2), Rho ( $\rho$ ), coefficient of correlation of error terms is (0.9480595) which is positive and statistically significant at $1 \%$ level of significance. The positive sign implies the two equations error terms have positive relationship. Moreover, since the values of Rho ( $\rho)$ is less than one, there is no perfect relationship between the random components of the responses in the initial bid and the second bid. Therefore, the two equations are interdependent and can be estimated simultaneously because the probability in which the null hypothesis that willingness to pay 
186 instead of univariate probit model, the two equations can be analyzed either using Seemingly 187 Unrelated Bivariate Probit model or Bivariate Probit model. However, in this study since the explanatory variables are not the same for both equations but still they are strongly correlated, seemingly unrelated bivariate probit regression estimation was employed. If the two equations 190 dependent variables depend on the same independent variable, bivariate probit model could be 191 applicable (Joseph N., 1996).

192 , a seemingly unrelated (SUR) bivariate probit model for an individual $i$ can be specified as follows 193 to identify the factors simultaneously determining the two WTP equation dependent variables 194 (Equation 1 and 2) based on (Haab and McConnell, 2002; Cameron and Trivedi, 2010) :

$$
W T P_{1 i}=X i \beta_{1 i}+\varepsilon_{1 i}
$$

$W T P_{2 i}=X_{2 i} \beta_{2 i}+\varepsilon_{2 i}$

197 Where $i=\mathrm{i}^{\text {th }}$ respondent's willingness to pay

$198 \beta_{1 i}$ and $\beta_{2 i}=$ are unknown parameters to be estimated in the first and second equation respectively $199 \mathrm{X}$ is a vector of explanatory variables that can affect amounts of offered bid values for improved 200 irrigation water supply

201 WTP1 and WTP2 = unobservable random components in the first and second equations 202 respectively

$203 \varepsilon_{1}$ and $\varepsilon_{2}$, are error terms normally distributed with mean zero and respective variances $\sigma_{1}$ and 204 $\sigma_{2}$, and have a bivariate normal distribution with correlation coefficient $\rho$. Where, $\rho \neq 0$

205 There four joint responses probabilities for the offered initial and follow up bids are: (Yes, Yes), 206 (Yes, No), (No, Yes) and (No, No) (Equation 3, 4, 5, 6). The probability of responses of respondent $207 \mathrm{i}$ to the first and the second offered bid valuses is given by (Haab and McConnell, 2002): $\operatorname{pr}(n o, n o)=\operatorname{pr}\left(W T P_{1 i}<t^{1}, W T P_{2 i}<t^{2}\right)$

$$
=p r\left(x_{i} \beta_{1 i}+\varepsilon_{1 i}<t^{1}, x_{i} \beta_{2 i}+\varepsilon_{2 i}<t^{2}\right) .
$$

$$
\operatorname{pr}(\text { no, yes })=\operatorname{pr}\left(W T P_{1 i}<t^{1}, W T P_{2 i} \geq t^{2}\right)
$$

$$
=\operatorname{pr}\left(x_{i} \beta_{1 i}+\varepsilon_{1 i}<t^{1}, x_{i} \beta_{2 i}+\varepsilon_{2 i} \geq t^{2}\right)
$$

$\operatorname{pr}($ yes,$n o)=\operatorname{pr}\left(W T P_{1 i} \geq t^{1}, W T P_{2 i}<t^{2}\right)$ 


$$
=\operatorname{pr}\left(x_{i} \beta_{1 i}+\varepsilon_{1 i} \geq t^{1}, x_{i} \beta_{2 i}+\varepsilon_{2 i}<t^{2}\right)
$$

$214 \operatorname{pr}($ yes, yes $)=\operatorname{pr}\left(W T P_{1 i} \geq t^{1}, W T P_{2 i} \geq t^{2}\right.$

$215=\operatorname{Pr}\left(X_{i} \beta_{1 i}+\varepsilon_{1 i} \geq t^{1}, X_{i} \beta_{2 i}+\varepsilon_{2 i} \geq t^{2}\right.$

216 Where $\mathrm{t}^{1}=$ amount of the first bid (Bid 1) and $\mathrm{t}^{2}=$ amount of the second bid (Bid 2)

\subsection{Estimation of the Mean Willingness to Pay}

219 Mean WTP can be estimated from double bounded dichotomous choice format using seemingly 220 unrelated bivariate probit model and open ended format of contingent valuation survey undertaken 221 in this study. Accordingly, the mean WTP of respondents from open ended format is simply 222 average of respondents maximum WTP (Equation 7).

223

$$
\text { Mean } W T P=\frac{1}{n} \sum_{i=1}^{n} y i
$$

224 Where $\mathrm{n}$ is the numbers of respondents and " $\mathrm{y}_{\mathrm{i}}$ " is the amount of respondents maximum WTP.

225 Furthermore, the mean WTP for improving conservation of the park from double bounded 226 dichotomous choice format using seemingly unrelated bivariate probit model can be estimated 227 using the following formula as Habb and McConnell (2002).

$228 \quad$ MWTP $=\frac{\alpha}{\beta}$

229 Where,

230 Where: MWTP = Mean willingness to pay,

$231 \alpha \square$ are constants/intercepts for the first and second equations

$232 \square \square$ are the coefficients of the first and second bid values in Seemingly Unrelated Bivariate 233 Probit model 


\begin{tabular}{lll}
\hline \multicolumn{1}{c}{ Variable description } & Variable type & Measurement \\
\hline Sex of respondent & Dummy & $1=$ Male headed, $0=$ Female headed \\
Age of respondent & Continuous & Year \\
Years of living in kebele & Continuous & Year \\
Livestock holding & Continuous & Tropical livestock unit \\
Total land holding size & Continuous & Hectare \\
Distance from home to park & Continuous & Kilometer \\
Family size in adult equivalent & Continuous & Number \\
Education status & Dummy & $1=$ literate, $0=$ Illiterate \\
Access to extension & Dummy & $1=$ having access; $0=$ Otherwise \\
Benefit of preservation & Dummy & $1=$ have benefit ; $0=$ Otherwise \\
Distance from farm to park & Continuous & Kilometer \\
Training/workshop on park & Dummy & $1=$ participated, $0=$ otherwise \\
conservation & & \\
Off/non-farm income & Dummy & $1=$ participate ; $0=$ otherwise \\
Amount of first bid price (Bid1) & Continuous & Birr \\
Amount of second bid price (Bid2) & Continuous & Birr \\
\hline
\end{tabular}

The dependent variables are WTP1 and WTP2 for seemingly unrelated bivariate probit analysis which has a dichotomous nature (Yes=1 and $\mathbf{0}=\mathbf{N o}$ ) measuring whether the households are willingness to pay or non-willingness to pay for the bid offered to improve conservation of Altash National park. The independent socio-economic variables which affects households' willingness to pay is described in Table 1.

Table 1: Description of Explanatory Variables and their Measurement 
3. Results and Discussion

\subsection{Socio-Economic Characteristics of Respondents}

Sample households were composed of both male and female headed. Of the total sample size of the study $84.69 \%$ were male headed while $15.31 \%$ were female headed households. The mean age of the respondent was 41.43 years with a minimum of 23 and a maximum of 75 years. $34.69 \%$ of respondents were illiterate, they cannot read and write and $65.31 \%$ were literate in which they can read and write. The maximum years of the respondent living in their current area was 50 years while the minimum was 2 years with average of 19.59 years. The average family size of the respondents was 3.07 with a minimum of 1 and maximum of 8.5 in adult equivalent. $78.06 \%$ of respondents have taken training on conservation of the park while the remaining $21.94 \%$ have not taken the training. The mean land holding size of the respondents was 4.75 ha with 0.3 and 15 hectare of minimum and maximum respectively.

\subsection{Households' WTP for Improving Conservation of the Park}

All of the respondents were willing to pay for improving conservation of the park. Double bounded dichotomous choice followed by open ended format of contingent valuation method was employed in this study. Accordingly, responses of respondent households for the initial and follow up bid values is shown in Table 1 thus, $73.47 \%$ of respondents accept both initial and follow up bid values (Yes, Yes), 8.67\% of respondents accept the initial offered bid value but reject the follow up bid value (Yes, No), $11.23 \%$ of respondents reject the initial offered bid value but they accept the second offered bid value (No, Yes); 6.63\% of respondents reject both offered initial and follow up bid values (No, No).

Table 2: Summary of responses for the offered initial and follow up bids

\begin{tabular}{lll}
\hline Joint responses & Frequency & Percentage \\
\hline Yes-Yes & 144 & 73.47 \\
Yes-No & 17 & 8.67 \\
No-Yes & 22 & 11.23 \\
No-No & 13 & 6.63 \\
Total & 196 & 100 \\
\hline
\end{tabular}


270

271

272

273

274

275

276

277

278

279

280

281

282

283

284

285

286

287

288

289

290

291

292

293

294

295

296

297

Respondent households' were also asked in which payment modality they prefer to pay the amount they would like to pay. Hence $76.02 \%$ of respondents prefer to pay through annual donation and the remaining $23.98 \%$ of respondents were preferred to pay through rural land use fee.

\subsection{Households' WTP Variation for Improvement of the Park conservation}

Table 3 shows results of seemingly unrelated bivariate probit model and marginal effects after seemingly unrelated bivariate probit model for households' WTP for the park conservation improvement. The marginal effect in the way that changes in WTP due to a unit change in the significant continuous explanatory variables and change from 0 to 1 for significant discrete variables was used to interpret the seemingly unrelated bivariate probit model estimates. Of fifteen explanatory variables nine variables were found to have statistically significant influence on respondents' WTP for conservation of the park. The probability of households' willingness to accept both the first and the second offered bid value (Yes, Yes) was 80.52\%, the probability of accepting the first offered bid value and rejecting the second bid (Yes, No) was 6.35\%. Moreover, the probability of households' rejecting the first offered bid and accepting the second bid was $1.15 \%$, the probability of households' protesting against both the first and the follow up bid was $11.98 \%$. Each statistically significant explanatory variables are also interpreted as follow:

The variable Years of living in kebelle is the number of years since the respondent households' living in that kebelles was found to be positively and statistically significant at $1 \%$ level of significance. The positive relationship implies that as households living more years in that particular kebelles have more awareness and feel sense of ownership for the park and willing to improve the conservation. The district was one of the area which the regional government selects for settlement and there are new settlers in the district. The marginal effect of this variable indicates that as the living of respondents in that kebelles increases by one year, the respondents' probability of willingness to pay for the conservation of the park increased by $87 \%$ keeping all other factors constant.

The dummy variable education status have positive and statistically significant influence on households' probability of willingness to pay for the park conservation improvement at $5 \%$ level 
of significance. The positive effect implies literate household heads have more awareness about environmental values and they are willing to pay for improvement. The study result reveals literate households' have $1.53 \%$ more probability to accept the offered bid values for the park conservation improvement compared to illiterate respondents keeping other factors constant. This finding is consistent with the findings of (Adams et al., 2008; Bhat \& Sinha, 2016).

Distance from home to park is found to have negative but statistically significant effect on households' willingness to pay for conservation of the park at 5\% level of significance. The negative relationship implies that households who are far from the park are less depend on the services from the park compared to households living in the vicinity of the park, as a result they are less willing to pay for the conservation of the park. The marginal effect of this variable shows that as the distance from households' home to the park increase by one kilometer, the probability of households' willingness to pay for the conservation of the park decreases by $0.09 \%$ keeping all other factors constant. This result is consistent with the findings of (Sherif, 2019b).

Benefit of preservation is a dummy variable which have positive and statistically significant relationship with the households' willingness to pay for park conservation improvement at $10 \%$ significance level. The marginal effect result of this variable implies that households who perceive conservation of the park will have benefit have $48.22 \%$ more probability to accept the offered bid values for the park conservation improvement compared to their counter parts i.e. households' who perceive conservation of the park will not have significant benefit.

Distance from farm to park was found to have positive and statistically significant influence on households' probability of accepting the offered bid values for the conservation of the park at $1 \%$ level of significance. The negative relationship shows households' who have farm land in the vicinity of the park are not interested if conservation of the park is improved because they want to expand their farm land through encroaching, they need the park for grazing of their animals and generally their dependency on the park is very high compared to households who have farm land far from the park. The result of the marginal effect indicates as the distance from farm to park increase by one kilometer, the probability of households' willingness to pay for improvement of the park conservation increases by $12.41 \%$ keeping other factors constant at their mean value.

Sex of the household head was found to have positive and statistically significant effect on households' willingness to accept the offered bid values for conservation of the park at $5 \%$ level 
of significance. The positive relationship implies that male headed households have more awareness about values of environmental resources and willing to pay for improvement compared to their counter parts. The result of the study reveals male headed households have $6.34 \%$ more likely willing to pay for conservation of the park keeping other factors constant at their mean value. This finding is consistent with the findings of (Assefa et al., 2017; Kamri, 2013).

The dummy variable training and/or workshop participation on the conservation of the park resources was found to have positive and highly significant effect on households' willingness to pay for conservation of the park at $1 \%$ level of significance. As the result of the study indicates households who took training on park conservation have $78.56 \%$ more willing to accept the offered bid values for conservation of the park. This result is contradicted with the findings of (Sherif, 2019b) but consistent with the findings of (Assefa et al., 2017b).

The coefficient of the first bid amount was found to have negative and statistically significant effect on households' probability of accepting the first offered bid amount for conservation of the park at 5\% level of significance. The negative relationship implies as the bid amount increases willingness to accept that bid amount decreases. This is consistent with the economic theory of law of demand. The marginal effect of this variable implies that as the initial offered bid amount increase by one Ethiopian birr, the probability of households' accepting the bid value decreases by $0.15 \%$ keeping other factors constant.

The coefficient of the second bid amount was also have negative but highly significant influence on households' probability of willingness to pay for conservation of the park at $1 \%$ level of significance, which is also consistent with the law of demand of economic theory. The marginal effect result shows as a one Ethiopian birr increase in the second bid amount, the probability of accepting the second bid decreases by $0.73 \%$ while keeping other variables constant at their mean value. 
356 Table 3: Estimated Marginal Effects for Seemingly Unrelated Bivariate Probit Model

\begin{tabular}{|c|c|c|c|c|c|c|}
\hline Variable & $\begin{array}{c}\text { Coefficient } \\
\text { (Equation 1) }\end{array}$ & $\mathbf{P}>\mathbf{Z}$ & $\begin{array}{c}\text { Coefficient } \\
\text { (Equation 2) }\end{array}$ & $\mathbf{P}>\mathbf{Z}$ & Marginal effect & $\mathbf{P}>\mathbf{Z}$ \\
\hline Sex & $.0632951(.0234)$ & 0.008 & $.0330608(.020)$ & 0.100 & $.06337(.025)$ & $0.015^{* * *}$ \\
\hline Age & $-.004167(.0132)$ & 0.752 & $-.0090097(.012)$ & 0.472 & $-.0021791(.003)$ & 0.502 \\
\hline $\begin{array}{l}\text { Years of living } \\
\text { in Kebele }\end{array}$ & .005655 (.003) & 0.025 & $.0268322(.018)$ & 0.154 & $.869968(.277)$ & $0.002 * * *$ \\
\hline Family size & $-.0034322(.039)$ & 0.931 & $.0794469(.065)$ & 0.225 & $.0165745(.014)$ & 0.268 \\
\hline Education status & $.2259177(.277)$ & 0.415 & $.5414024(.260)$ & 0.037 & $.015314(.007)$ & $0.044 * *$ \\
\hline $\begin{array}{l}\text { Distance from } \\
\text { home to park }\end{array}$ & $-.0063141(.002)$ & 0.003 & $-.0024827(.001)$ & 0.146 & $-.00094(.001)$ & $0.044 * *$ \\
\hline $\begin{array}{l}\text { Off/non farm } \\
\text { income }\end{array}$ & $-.5887437(.266)$ & 0.027 & $-.1684432(.239)$ & 0.483 & $-.0938228(.069)$ & 0.179 \\
\hline $\begin{array}{l}\text { Access to } \\
\text { extension }\end{array}$ & $-1.2563(.426)$ & 0.003 & $-.4778451(.502)$ & 0.341 & $-.1195915(.077)$ & 0.122 \\
\hline $\begin{array}{l}\text { Benefit of } \\
\text { preservation }\end{array}$ & $.6703079(.275)$ & 0.015 & $.1412918(.085)$ & 0.1000 & $.4822271(.275)$ & $0.080^{*}$ \\
\hline $\begin{array}{l}\text { Distance from } \\
\text { farm to park }\end{array}$ & $.006451(.002)$ & 0.010 & $.0073108(.001)$ & 0.000 & $.1241328(.029)$ & $0.000 * * *$ \\
\hline $\begin{array}{l}\text { Livestock } \\
\text { holding }\end{array}$ & $-.1378332(.291)$ & 0.637 & $.6690606(.275)$ & 0.015 & $.0253789(.076)$ & 0.739 \\
\hline Landholding size & $-.0024691(.053)$ & 0.963 & $.0137045(.050)$ & 0.784 & $.0027357(.013)$ & 0.837 \\
\hline $\begin{array}{l}\text { Training on park } \\
\text { conservation }\end{array}$ & $.7748295(.299)$ & 0.010 & $.001234(.001)$ & 0.073 & $.7856248(.286)$ & $0.006 * * *$ \\
\hline Bid1 & $-.0169694(.007)$ & 0.031 & & & $-.001475(.001)$ & $0.034 * *$ \\
\hline
\end{tabular}




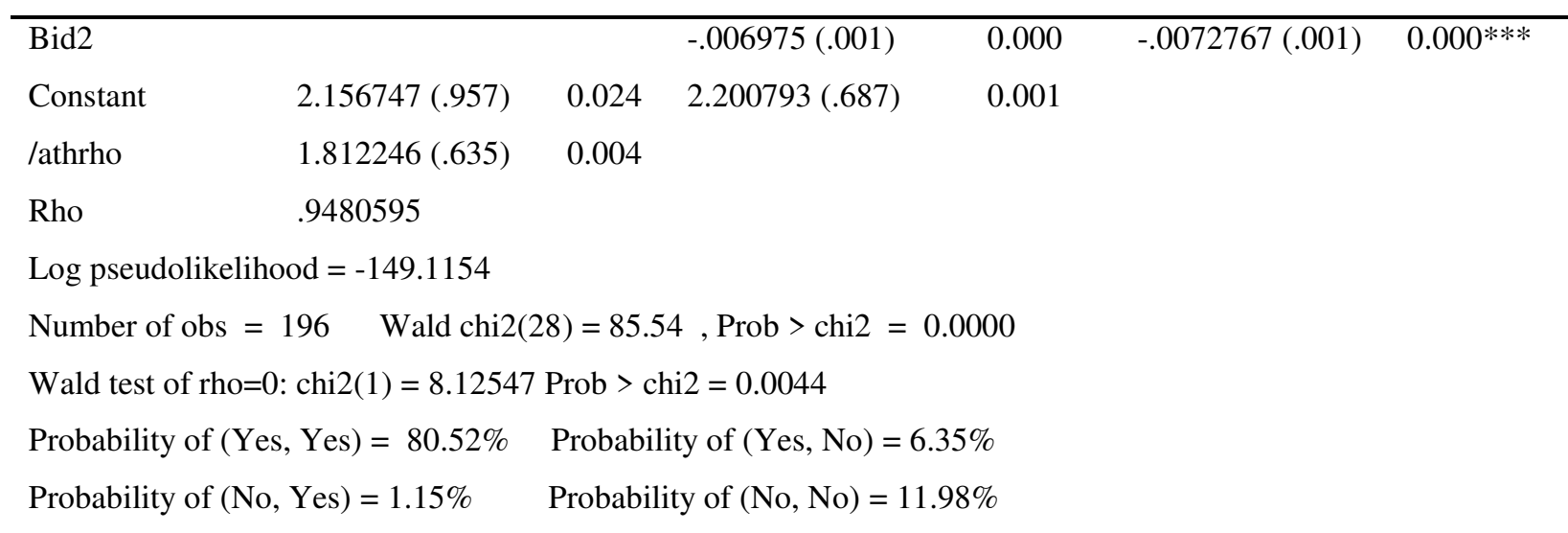

Source: Own computation from field survey data, 2021

Note: $* * *, * *$ and $*$ represents significance level at $1 \%, 5 \%$ and $10 \%$, respectively Numbers in parenthesis are robust standard Errors

3.4. Households' Mean WTP for Improving Conservation of the Park

\subsubsection{Estimation of Mean WTP from Double Bounded Dichotomous Choice Format (Bivariate probit model)}

The coefficient of the first bid and the follow up bid in seemingly unrelated bivariate probit model was used to estimate the mean willingness to pay of respondent households for double bounded dichotomous choice format of contingent valuation method. As it is shown in table 2 the coefficient of both the first bid and second bid amount were negatively and statistically significant. The negative sign indicates there is inverse relationship between households' willingness to pay for conservation of the park and amount of bid values. As it is described in the methodology section, the mean WTP for conservation of the park from double bounded dichotomous choice format using seemingly unrelated bivariate probit model is estimated using the following formula as Habb and McConnell (2002). 
$378 \quad$ Mean $W T P=\frac{-\alpha}{\beta}$

379 Where,

380 Where: WTP $=$ Willingness to pay,

$381 \alpha \square$ are constants/intercepts for the first and second equations

$382 \square \square$ are the coefficients of the first and second bid values in seemingly unrelated bivariate probit

383 model

384

385

386

387

388

Therefore, the mean willingness to pay for the first and the second equation is 127.1 and 315.53

birr respectively. On average the mean willingness to pay from double bounded dichotomous

choice format is 221.32 birr by taking average of the mean WTP for equation one and equation two as follows (Lamesgin, 2017).

Mean WTP $=\frac{\frac{-\alpha 1}{\beta 1}+\frac{-\alpha 2}{\beta 2}}{2}=\frac{\frac{-2.156747}{0.0169694}+\frac{-2.200793}{-0.006975}}{2}=221.32 \mathrm{birr}$

\subsubsection{Estimation of Mean WTP from Open Ended Format}

The households' mean willingness to pay for conservation of the park also estimated from the open ended survey of contingent valuation method employed in this study. Therefore the mean willingness to pay of households' from the open ended format is 223.52 birr per household per year which is only marginally higher than the mean willingness to pay for households from double bounded dichotomous choice format which is 221.32 birr per household per year since households have a tendency to state their maximum WTP in open ended format close vicinity to their highest offered accepted second bid value of the double bounded dichotomous choice format. 


\subsection{Households' Aggregate WTP for Conservation of the Park}

The expected aggregate willingness to pay was estimated from both the double bounded dichotomous choice format and open ended format of the contingent valuation method employed in this study. The aggregate WTP was computed by multiplying the mean WTP by the total number of households living in the six vicinity kebelles of the park. Based on the information obtained from Quara district Agricultural office (2020), the total number of households in the six kebelles which are vicinity of the park was 6828. Therefore, the expected aggregate WTP was estimated 1,511,172.96 and 1,526,194.56 birr from the double bounded dichotomous choice and open ended format respectively.

\subsection{Conclusions and Policy Implication}

In this study, contingent valuation method in double bounded dichotomous choice format followed by open ended format was used to state households' willingness to pay for conservation of the Altash National park. Seemingly unrelated bivariate probit model was used to analyse determinants of households' WTP variation for conservation of the park. Accordingly, Sex of respondent, Years of living in Kebelle, Education status, Distance from home to park, Benefit of preservation, Distance from farm to park, Training on park conservation, and the first and second offered bid values were found to have statistically significant effect on households' WTP variation. Respondents' mean WTP for conservation of the park was estimated 221.32 and 223.52 birr per year from double bounded dichotomous choice and open ended format respectively. 1,511,172.96 and1,526,194.56 birr was the calculated expected aggregate WTP from double bounded dichotomous choice and open ended format. Based on the findings all respondents were willing to pay for improvement of the park conservation, therefore, participation of the community should be considered for formulation of policies and strategies and in any decision making process related with conservation of the park. Furthermore, regular training should be given for the community particularly for the new settlers in order to enhance their awareness about the value of the park and develop sense of ownership. 
436 Ethics approval and consent to participate

437 Not applicable

438 Consent for publication

439 Not applicable

$440 \quad$ Availability of data and materials

441 All authors declare that the datasets used in this manuscript are fully available upon request from

442 the corresponding author.

443 Competing interests

444 The authors declare that they have no any competing interests in this manuscript.

$445 \quad$ Funding

446 This work was supported by the University of Gondar, Ethiopia

447 Authors' contributions

448 All authors has been actively involved in making a crucial contribution to the design and 449 completion of this research, interpretation of data and conclusions, assisted in drafting and revising 450 the manuscript, read and approved the final submitted manuscript.

451 Acknowledgements

452 We are grateful for the University of Gondar for funding this study. We are also very grateful for 453 Quara district administrative for their cooperation during data collection and providing 454 supplementary secondary data. Last but not least, we thank the respondents of this study in the 455 Quara district for their time and willingness in providing data for the study. 


\section{References}

Adams, C., Seroa da Motta, R., Ortiz, R. A., Reid, J., Ebersbach Aznar, C., \& de Almeida Sinisgalli, P. A. (2008). The use of contingent valuation for evaluating protected areas in the developing world: Economic valuation of Morro do Diabo State Park, Atlantic Rainforest, São Paulo State (Brazil). Ecological Economics, 66(2-3), 359-370. https://doi.org/10.1016/j.ecolecon.2007.09.008

Ahmed, S. U. and Gotoh, K. (2006); The Choice of Elicitation Methods in CVM and their Impact on Willingness To Pay in Environmental Assessment.

Assefa, A., Abafita, J., \& Etensa, T. (2017a). Economic Valuation of Borena-Sayint National Park, Ethiopia : An Application of Contingent Valuation Method, 7(12), 14-27.

Assefa, A., Abafita, J., \& Etensa, T. (2017b). Economic Valuation of Borena Sayint National Park: An Application of Contingent Valuation Method Economic Valuation of Borena-Sayint National Park, Ethiopia: An Application of Contingent Valuation Method. Journal of Environment and Earth Science, 7(12), 14-27. Retrieved from www.iiste.org

Bekele, A \& Mengesha, G. (2008). Diversity and Relative Abundance of Birds of Altash National Park , North Gondar , Ethiopia, 34(2), 215-222.

Bhat, M. Y. (2016). Valuation of National Parks : An individual travel cost approach. International Journal of Multidisciplinary Research and Development, 3(3), 7-12.

Bhat, M. Y., \& Sinha, A. (2016). Willingness to Pay for Preserving National Park Biodiversity: A Case Study. Economy, 3(2), 102-107. https://doi.org/10.20448/journal.502/2016.3.2/502.2.102.107

Cameron, T. A. and Quiggin, J. (1994). Estimation using contingent valuation data from a dichotomous choice with follow-up questionnaire. Journal of Environmental Economics and Management, 27(3):218-34.

Cameron, A.C. and Trivedi, P.K., 2010. Microeconometrics using stata (Vol. 2). College Station, TX: Stata press.

Endalew, B., Tassie, K., \& Ayalew, Z. (2018). Non-Market Measurement Techniques of Willingness to Pay, the Case of Environmental Resources: A Review. J. Agric. Environ. Sci, 3(2), 1-14. Retrieved from 
https://journals.bdu.edu.et/index.php/jaes/article/view/196/291\%0Ahttps://journals.bdu.edu.et/index. php/jaes/article/view/196

Gebre T, Dessie M, Hagos S, Getachew M, Sinshaw M, (2016). An Assessment of Risks and Opportunities Related to Ecosystem Services, in the Case of Mekelle City. Journal of Ecosystem \& Ecography 6 (4).

497 Haab, T.C. and McConnell, K.E. 2002. Valuing environmental and natural resources: the econometrics of 498 non-market valuation. Edward Elgar Publishing.

499

Haefele, M., \& Loomis, J. B. (2016). Total Economic Valuation of the National Park Service Lands and Programs: Results of a Survey of the American Public. SSRN Electronic Journal, (January).

503

Joseph N. (1996, September). Stata Technical Bulletin (STB). Retrieved from stata@stata.com.

505

506

Kamri, T. (2013). Willingness to Pay for Conservation of Natural Resources in the Gunung Gading National Park, Sarawak. Procedia - Social and Behavioral Sciences, 101, 506-515. https://doi.org/10.1016/j.sbspro.2013.07.224

509

Kothari, C. R. (2004). Research Methodology: Methods and Techniques, $2^{\text {nd }}$ Edition.New Age International, New Delhi, India.

512 Lamesgin Tebeje. 2017. Households' Willingness to Pay for Soil Conservation Practices on Cultivated

513 Land in South Achefer District, Amhara National Regional State of Ethiopia: A Contingent Valuation

514 Approach

515

MEA (2005), Ecosystems and human well-being: the assessment series. Millennium Ecosystem

517 Assessment (MEA). Washington, DC, Island Press.

518

Mossie, H., Adem, M., \& Aynalem, M. (2019). Review on Economic valuation and conservation of

520

521 PAN UK (2017). Experiences with ecosystem services walks in Ethiopia. national park of Ethiopia. The International Journal of Business Management and Technology, 3(1).

522 Quara district Agricultural office (2020), total households of the district. 
524 Sahle Tesfaye (2019). Assessment of Ecosystem Services for Sustainable Management of Lake Hawassa

525 and Its Biodiversity, Southern Ethiopia. International Journal of Scientific \& Engineering Research 526 10(2):230-236

527 Shamsudin, M. N., R., N., Radam, A., \& Shuib, A. (2009). Willingness to Pay towards the Conservation 528 of Ecotourism Resources at Gunung Gede Pangrango National Park, West Java, Indonesia. Journal of Sustainable Development, 2(2). https://doi.org/10.5539/jsd.v2n2p173

530

Sherif, H. M. (2019a). Determinant of Household Willingness to Conserve Gibe Sheleko National Park : An Application of Contingent Valuation Method ( CVM ). International Journal of Economics \&

Sherif, H. M. (2019b). Determinant of Household Willingness to Conserve Gibe Sheleko National Park : An Application of Contingent Valuation Method ( CVM ). International Journal of Economics \& Management Sciences, 8(1), 1-8. https://doi.org/10.4172/2162-6359.1000559.

Walle, Y. (2015). Local Community's Valuation of E cological Conservation Benefits of Semien 